\title{
Don't let the sun go down on me: The German constitutional court and its Lisbon judgement
}

Citation for published version (APA):

Hoffmann, L. (2009). Don't let the sun go down on me: The German constitutional court and its Lisbon judgement. Journal of Contemporary European Research, 5(3), 50-68.

Document status and date:

Published: 01/01/2009

\section{Document license:}

Unspecified

\section{Please check the document version of this publication:}

- A submitted manuscript is the version of the article upon submission and before peer-review. There can be important differences between the submitted version and the official published version of record.

People interested in the research are advised to contact the author for the final version of the publication, or visit the DOI to the publisher's website.

- The final author version and the galley proof are versions of the publication after peer review.

- The final published version features the final layout of the paper including the volume, issue and page numbers.

Link to publication

\footnotetext{
General rights rights.

- You may freely distribute the URL identifying the publication in the public portal. please follow below link for the End User Agreement:

www.umlib.nl/taverne-license

Take down policy

If you believe that this document breaches copyright please contact us at:

repository@maastrichtuniversity.nl

providing details and we will investigate your claim.
}

Copyright and moral rights for the publications made accessible in the public portal are retained by the authors and/or other copyright owners and it is a condition of accessing publications that users recognise and abide by the legal requirements associated with these

- Users may download and print one copy of any publication from the public portal for the purpose of private study or research.

- You may not further distribute the material or use it for any profit-making activity or commercial gain

If the publication is distributed under the terms of Article $25 \mathrm{fa}$ of the Dutch Copyright Act, indicated by the "Taverne" license above, 


\section{Don't Let the Sun Go Down on Me:}

\section{The German Constitutional Court and Its Lisbon Judgement}

\section{Introduction: The Karlsruhe Conundrum}

It was in May 2000 that Joschka Fischer spent ninety minutes in front of a gathered audience at Berlin's Humboldt University with his Foreign Minister-hat 'removed'. In his speech Fischer outlined a bold and ambitious vision for the European Union ${ }^{1}$ and followed a tradition of post-war German politicians championing European unity and integration. ${ }^{2}$ In fact, Fischer's speech inspired other heads of state and government at the time so much that a significant number of leaders followed his lead and delivered their own vision of Europe during the following six months ${ }^{3}$. This started off what was to become the Debate on the Future of Europe ${ }^{4}$ that culminated in the Convention on the Future of Europe, ${ }^{5}$ the Treaty establishing a Constitution for Europe ${ }^{6}$ and later on the Lisbon Treaty. The German Constitutional Court in its June 2009 judgement on said Treaty, ${ }^{7}$ though declaring it compatible with the German Basic Law, failed to live up to the visionary example set by many German politicians and pointed out above. Instead the Court positioned itself as a euro-sceptic voice seemingly poised to slow down the European project - if not determined to strike down any future attempts at integration in new policy areas.

\footnotetext{
${ }^{1}$ Fischer (2000).

${ }^{2}$ Former German Chancellors Konrad Adenauer, Helmuth Schmidt and Helmuth Kohl were all known for their outspoken support and vision of a united Europe.

${ }^{3}$ See, e.g. Blair (2000); Chirac (2000); Jospin (2000); Rau (2001).

${ }^{4}$ The dedicated Futurum website and since been taken offline by the European Commission.

${ }^{5}$ See http://european-convention.eu.int.

${ }^{6}$ Official Journal of the European Union (2004).

${ }^{7}$ BVerfG, 2 BvE 2/08 vom 30.6.2009, Absatz-Nr. (1 - 421). See also http://www.bverfg.de/entscheidungen/es20090630_2bve000208.html
} 
Although the President of the Court's Second Senate proclaimed that 'Das Grundgesetz sagt ' $J a^{\prime}$ zum Vertrag von Lissabon', ${ }^{, 8}$ it ruled that the accompanying laws passed by the Bundestag to incorporate the Lisbon Treaty $^{9}$ needed to be revised before German ratification could be completed. In Germany, the judgement meant that the pro-Lisbon majority among the national political leadership - across both government and opposition parties - were reassured that the ratification process could be completed prior to the second Irish referendum, scheduled for 2 October 2009. Yet, the Lisbon-critical forces were also encouraged mainly because of the 72 pages of 'small print' ${ }^{10}$ that the judges deemed necessary in order to explain their decision which turned the 'Ja zu Lissabon' effectively into a 'Ja, aber...'.

The detailed legal ramifications and judicial nuances of the treaty have been commented on already. ${ }^{11}$ The aim of this paper is to explore the political consequences that the legal reasoning of Europe's most influential national constitutional Court may have on the future relationship between Germany and the EU as well as the European integration project as a whole. It is clear that the judgement is not a ringing endorsement of the European integration process. Rather the Court uses its long verdict to establish itself as the national guardian of German sovereignty on the basis of the legal boundaries set by the Grundgesetz. Of course, the Court is within its rights to do so - but it is not obliged to do so because it is interpreting the existing legal status. As many commentators would agree with, the judges' interpretation is far from uncontroversial. Thus, this article sets out to make a normative argument about the judgement's shortcomings and its potential

\footnotetext{
${ }^{8}$ See http://www.tagesschau .de/inland/lissabon102.html.

${ }^{9}$ For the vote on the issue, see Bundestag Stenographisher Bericht 16/157, S. 16483 A (http://dip21.bundestag.de/dip21/btp/16/16157.pdf); for the text of the original accompanying laws see Bundesdrucksache 16/8489 (http://dipbt.bundestag.de/dip21/btd/16/084/1608489.pdf) and Bundesdrucksache 16/8919 (http://dip21 .bundestag.de/dip21/btd/16/089/1608919.pdf).

${ }^{10}$ The English language version has 72 pages - slight variations in length of the German version may be possible.

${ }^{11}$ For a critical view see Halberstam and Möllers (2009) and for a supportive analysis see Schorkopf (2009).
} 
political ramification for German-EU relation as well as the wider European integration process. The judgement addresses a wide range of important issues related to legitimacy, democracy and sovereignty. The following sections will address these issues by exploring the Court's reasoning with regards to the division of competences between the national and European level, the legitimacy of the European Parliament as a supranational assembly and the role of national parliaments in the European integration process.

\section{The ultra vires virus}

The Court clearly used the Lisbon judgement to elaborate on its 1992 Maastricht decision $^{12}$, in which it declared the Treaty of Maastricht as compatible with the Grundgesetz but claimed legal guardianship over potential infringements by the EU into areas of national, i.e. German, competences. ${ }^{13}$ In spite of its words, the Court, however, never acted upon the implied Maastricht 'promise' to use ultra vires judicial review to control or even prevent an expansion of EU legislation and competences and thereby defending the sovereignty of the German legal system. The fact that it is brought up again seems to indicate its readiness to take up the task that the Court set itself first in the 1973 Solange Judgement ${ }^{14}$ and followed up in its judgements of $1987^{15}$ and 1992 (Maastricht) seventeen years ago.

A clear indication for the Court's ambition to become more active and use ultra vires reviews to contain integrationist moves, is the list of competences that have 'always been deemed especially sensitive for the ability of a constitutional state to democratically shape itself. ${ }^{16}$ Clearly, what is meant by this is that there are certain policy areas that must remain at the national level if sovereign member states continue to exist and are not

\footnotetext{
${ }^{12}$ Bverfg, Case 2 BVR 464/98.

${ }^{13}$ Weiler (1995) and Baquero Cruz (2008).

${ }^{14}$ BverfGE 37, 271 (Solange I).

${ }^{15}$ BverfGE 73, 339 (Solange II).

${ }^{16}$ BVerfG, 2 BvE 2/08 vom 30.6.2009, Absatz-Nr. 252.
} 
to dissolve into a fully federated European Union. According to the verdict, these areas are for instance criminal law, the use of force (police and military), fiscal policy, the social state, and cultural policies including education, family and religious law and laws regulating religion. The list seems arbitrary and the Court gives no indication as to the reasoning behind its selection. Policy areas such as the power to print money or conducting trade negotiations would surely be considered 'state-defining' to the same extent as the five issues listed by the Court. Despite a vivid and ongoing debate in academia about the Europeanisation of private law, ${ }^{17}$ there is no mentioning of this legal area in the Court's list. Although Lisbon does not explicitly grant new powers to the EU in these new policy areas, they are, of course, those policy fields in which further integration is expected over the coming years. For the German Court to include this seemingly arbitrary list must surely mean that, after the warning shots that were given up by the 1992 Maastricht judgement (in a time when the popular support of the European integration project was much more pronounced), it is now preparing to take a much more active part in monitoring the detailed effect of EU integration on the German legal and political system.

Of course, the Lisbon Treaty itself is not attempting to transfer powers in any of these policy areas from the national to the EU level. Thus, the Court does not see any reason to strike down the Treaty on the basis of competence transfer. So why address the issue of state sovereignty in the first place? Considering that the Court's overall euro-cautious tone applies throughout the judgement, it seems clear that the judges foresee future treaty changes or even competence expansion based on the current Treaty Article 308 EC (see below). The Court is thus positioning itself to potentially strike down these integrationist moves. By including a state-defining competence list, the Court lays the legal foundation

\footnotetext{
${ }^{17}$ See, e.g., the H.i.i.L. Project on 'National Resistance to the Europeanisation of Private Law' at the University of Tilburg; www.tilburguniversity.nl/faculties/law/research/ticom/research/hiil nrepl.
} 
upon which it can build its ultra vires reviews of future EU legislation or even competence expansion by preventing 'legal instruments $[\ldots]$ that transgress competences or that violate constitutional identity $[\ldots]$ and $[\ldots]$ keep within the boundaries of the sovereign powers accorded to them by way of conferred power. ${ }^{18}$ The Court even goes as far as to stipulate that the German legislature would need to create a new legal mechanism specifically aimed at facilitating ultra vires review 'to safeguard the obligation of German bodies not to apply in Germany, in individual cases, legal instruments of the European Union that transgress competences or that violate constitutional identity. ${ }^{19}$ Clearly, all indications suggest that - Lisbon or no Lisbon - we can brace ourselves for a much more euro-critical German Constitutional Court that is keen to scrutinize EU legislation in order to safeguard the German legal order against any further integrationist moves.

\subsection{0 for 1 or the EP slap-down}

In its build-up to striking down the accompanying laws that are required to make the Lisbon Treaty legally applicable in Germany, the Court seemingly en passant takes a swing at the European Parliament by raising questions of its legitimacy and democratic viability as a democratic actor. The Bundesverfassungsgericht acknowledges that the EP may contribute to the legitimacy of the European Union but in its view it cannot.

The key criticism by the Court is based on the fact that the election procedure to the European Parliament is not based on a strict one-person one-vote principle. Instead there are national quotas that allocate a specific number of seats to each member state. The numbers are adjusted to broadly reflect the population size of the different members but, of course, they are not exactly proportional. The Court elaborates on this point and, whilst

\footnotetext{
${ }^{18}$ BVerfG, 2 BvE 2/08 vom 30.6.2009, Absatz-Nr. 241.

${ }^{19}$ BVerfG, 2 BvE 2/08 vom 30.6.2009, Absatz-Nr. 241.
} 
striking down the case's complainant's claim that this means that the EU is undemocratic and thus the Treaty of Lisbon is incompatible with the German Basic Law, elaborates on its view that the European Parliament 'is not a body of representation of a sovereign European people ${ }^{20}$. 'The fundamental rule of electoral equality thus 'only applies within a people, not in a supranational body of representation, which remains a representation of the peoples linked to each other by the Treaties. ${ }^{21}$ Of course, from a practical perspective the EP can never be a one-person one-vote chamber, due to the very nature of the European Union as a Union of states and peoples. In such a sui generis union, even the lower chamber, in federal state system the one that is traditionally much more (though never completely $)^{22}$ proportionate in its representation, must always allow smaller countries and their citizens to be represented. Since the European Parliament would need to have at least 1230 seats for all member states to have at least one seat, it is very likely that the EU will never adopt a fully proportionate system. The problem arises from the logic that the Court takes away from this: 'the European Union, as a supranational organisation, must comply as before with the principle of conferral that is exercised in a restricted and controlled manner.' ${ }^{23}$ 'The deficit in the direct track of legitimisation of the European public authority that is based on the election of the Members of the European Parliament. ${ }^{24}$ Thus, in characterising the EU as a supranational organisation, and (only thereby) deeming the Treaty of Lisbon as compatible with the German constitution, the Court denies any developments towards a politically more integrated Union. It seems that the Bundesverfassungsgericht uses its judgement to draw a line in the sand. As the Lisbon Treaty comes right up to this line, future integration attempts look like they are destined

\footnotetext{
${ }^{20}$ BVerfG, 2 BvE 2/08 vom 30.6.2009, Absatz-Nr. 280.

${ }^{21}$ BVerfG, 2 BvE 2/08 vom 30.6.2009, Absatz-Nr. 279.

${ }^{22}$ Even in Germany with the frequent occurrence of Überhangmandate as well as the 5 per cent threshold a misrepresentation of parties in relation to their actual share of the votes is the norm. This is without even considering the parliamentary legitimacy according to the German Constitutional Court with regards to the Bundesrat (which the Court deems to 'be [...]a chamber of a National Parliament') or even the election of the US President.

${ }^{23}$ BVerfG, 2 BvE 2/08 vom 30.6.2009, Absatz-Nr. 298.

${ }^{24}$ BVerfG, 2 BvE 2/08 vom 30.6.2009, Absatz-Nr. 293.
} 
to be bounced back (behind the line) by the Karlsruhe Court. It is therefore not so much what the Court says about Lisbon with respect to EP legitimacy but rather what it says about the nature of the European Union and the essence of the European integration process that makes this a judgement that will most certainly come back to haunt the Europhiles among us.

\section{The Bundestag to the Rescue}

The Court's analysis of legitimacy in the Union of 'conferred powers', is then cleverly linked to the issue of legitimacy through the citizens at the member state level. The Court, facing a Union that is not a federal state but only a Staatenverbund ${ }^{25}$ clarifies that legitimacy must therefore come from the citizens through national elections and national parliaments to the EU level of governance. It refers explicitly to the 'legitimising connection of elections and other votes [...]. ${ }^{26}$ And whilst not striking down the Lisbon Treaty, the Court goes on to rule that a revision of the accompanying laws that were passed by the Bundestag and Bundesrat in April 2008 is necessary. The Court's reasoning provided for the requirement for redrafting these focuses on two issues in the Lisbon Treaty: the passerelle clause (Article 48.7 TFEU) and the flexibility clause (Article 352 TFEU). The former allows member state governments, by a unanimous vote in the European Council (and following consent by national parliaments as well as the European Parliament) to move existing competences from a special legislative procedure (i.e. unanimity voting) to the ordinary legislative procedure (i.e. qualified majority voting). The latter provides for the possibility to obtain legislative power for the Union to achieve specific objectives already set out in the Treaties, but where the Treaties have not provided the necessary powers to the European Union. This clause is based on the current

\footnotetext{
${ }^{25}$ Unfortunately, the Court does not provide us with a definition of this newly created term.

${ }^{26}$ BVerfG, 2 BvE 2/08 vom 30.6.2009, Absatz-Nr. 295.
} 
Article $308 \mathrm{EC}$, which, however, is restricted to just the objective of the common market as opposed to Article 352 TFEU that refers to all 'objectives set out in the Treaties'.

The German Court maintains that the involvement of the German legislature is crucial in these areas. The accompanying laws that were originally passed by the Bundestag and the Bundesrat are therefore not sufficient to guarantee the necessary scrutiny of the German government when applying either Article 352 or 48.7 TFEU. The Court insists that the government can only act at the European level with regards to these articles if and when it has received prior approval/instruction to do so by the Bundestag and - where necessary - the Bundesrat. According to the judgement only the explicit approval of the German legislature can provide the necessary legitimacy to increase EU competences.

The judgement requires the legislator to strengthen the position of the Bundestag and Bundesrat $^{27}$ vis-à-vis the European integration process and requires the German government to consult much more extensively with the German Parliament. ${ }^{28}$ The incorporation of national parliaments into the European decision-making process has been a popular subject and the idea was first launched in the Declaration on the Future of Europe $^{29}$ annexed to the Treaty of Nice that called on the member state governments to consider 'the role of national parliaments in the European architecture.' ${ }^{30}$ The Treaty of Lisbon took care of this idea and included a Protocol on the Role of National Parliaments ${ }^{31}$ that provides for a special procedure whereby national parliaments can block EU legislation and force the Commission to re-evaluate its legislative proposals.

\footnotetext{
${ }^{27}$ The Bundesrat is only involved if and when relevant legislation affects the area of competence of the German Länder.

${ }^{28}$ Interestingly, the Constitutional Court also strengthened the role of the parliament vis-à-vis the government in two other - non-Europe related - judgement that followed the Lisbon judgement. See http://www.bundesverfassungsgericht.de/entscheidungen/es20090617 2bve000307.html and http://www.bundesverfassungsgericht.de/entscheidungen/es20090701 2bve000506.html.

${ }^{29}$ European Union (2001).

${ }^{30}$ European Union (2001).

${ }^{31}$ See http://eur-lex .europa.eu/LexUriServ/LexUriServ .do?uri=OJ:C:2007:306:0148:0150:EN:PDF.
} 
However, the German Constitutional Court states that in cases when either the passerelle or the flexibility clauses are used, the Bundestag's tacit approval cannot be taken for granted. Rather it is necessary for the German legislature to empower explicitly the German government to act at the EU level with regard to the aforementioned articles. It seems that the Court is thereby impeding the use of the two clauses by complicating the related national procedures. The fact that this would at best slow-down and at worst prevent future integrationist moves can be regarded as a welcome, if not wanted, byproduct. In fact, in light of the arguments made in the previous section, it seems clear that the Court finds that the aforementioned metaphorical line is crossed by the Lisbon Treaty's passerelle and the flexibility clauses (the same is also true for the more restricted 'emergency brake procedure' of Articles 82.2 and 82.3 TFEU - see below). And though the Bundesverfassungsgericht does not strike down the Treaty, it installs instead stricter national control in order to prevent the clauses from being used to transfer any new or additional powers from the national to the EU level. In my view, the effectiveness of its ruling on this matter is questionable for three reasons.

First, the judgement implies that the Bundestag has a distinct role not only to be informed by the German government (see Article 23.3 of the Grundgesetz) ${ }^{32}$ but to control and instruct it actively in the application of the two Lisbon Treaty articles 48.7 and 352. Of course it is important that any government informs its parliament of its activities, be it at the national, international or European level. Yet, it is questionable whether the government should be restricted in its activities, especially at the European and international level, by the need for explicit instructions to act. This is what the Lisbon judgement does: it restricts the German government in its capability to act at the European level, because the Bundesverfassungsgericht demands that any action needs to be first authorised by the German Parliament. The government may only act 'if the

\footnotetext{
${ }^{32}$ See http://www.bundestag.de/dokumente/rechtsgrundlagen/grundgesetz/index.html.
} 
German Bundestag and the Bundesrat have adopted within a period yet to be determined a law pursuant to Article 23.1 of the Basic Law which takes the purpose of Article 48.7(3) TEU Lisbon as an orientation. ${ }^{33}$ The use of 352 TFEU requires "constitutionally [...] ratification by the German Bundestag and the Bundesrat on the basis of Article 23.1 sentences 2 and 3 of the Basic Law. ${ }^{34}$

According to my understanding of legitimacy and national parliaments, it is not evident why these houses of parliament should hold a legitimate mandate to participate in the decision-making procedure at the European level ${ }^{35}$ National MPs are elected to form and hold to account their national government for its actions. But they do no not have a mandate to participate directly or indirectly in the decision-making process at the European level. This does not mean that a parliament should not control the government when it makes decision related to the EU, foreign policy, or even military actions. The argument made here is related to areas that do not fall within national competences, i.e. already existing European competence and thus areas in which national parliament no longer have a legislative prerogative and it is the governments that act in the best interest of their citizens. National parliaments should make sure that the government does exactly that: act in the best national interest but they should not be encouraged to legislate actively in areas and on policies for which they did not receive a mandate by their respective electorate. Furthermore, national parliamentarians are unlikely to have the necessary knowledge to form informed and independent opinions on subject matters that fall outside their legislative competences. Thus, the only motivation for parliamentarians to 'control' the government in these specific decisions surrounding Treaty Articles 48.7 and 352 would be to score national political points which can hardly be the intention of

\footnotetext{
${ }^{33}$ BVerfG, 2 BvE 2/08 vom 30.6.2009, Absatz-Nr. 319.

${ }^{34} \mathrm{BVerfG}, 2$ BvE 2/08 vom 30.6.2009, Absatz-Nr. 328.

${ }^{35}$ See also Kiiver (2006); Donnelly and Hoffmann (2003).
} 
the Grundgesetz's Article 23 which regulates the relationship between Germany and the European Union (which is incidentally the Article that the Court cites in demanding a closer and more active involvement of the Bundestag).

Second, there is a substantial body of academic literature that questions the effectiveness of legislative control with regard to executive actions. ${ }^{36}$ This is of course not the place to analyse the German political system with a view to the effectiveness of the Bundestag to control the government. Yet, it is useful to point out that the German constitution seems to be much more concerned with guaranteeing a stable government through solid and continuous support by the Parliament than to arm it with legal and political weapons to scrutinise its every move. Historically, this is only logical given the experiences of the Weimar Republic. Practically it means that one of the key tasks of the German parliament is to provide the government with a working majority. ${ }^{37}$ Therefore, the governing parties will always control a majority in the Bundestag. It may be legally possible, yet, politically unlikely, that MPs from the same political party/parties that form the government at would withdraw their support for governmental actions at the European level (or on any other issues). Internal consultations as well as executive authority (especially with regard to European matters) make an effective and impartial scrutiny of the German government by the Bundestag unlikely. When combining this with the existing pro-European consensus among the current parliamentary parties (including the two largest ones, CDU and SPD), it seems inconceivable that the German parliament would stop the German government from taking decisions at the European level, that, after all, the government deems to be in Germany's best interest. The current German political reality and constitutional tradition notwithstanding, the Court in its judgement is not only

\footnotetext{
${ }^{36}$ See Hayward (2004) and Larking (2008).

${ }^{37}$ Note the 'constructive vote of no-confidence', which prevents parliament from creating a power vacuum by dismissing a government without installing a new one.
} 
encouraging, but demanding closer scrutiny for the government's action at the EU level. Failing to do so, or so the judgement leads us to believe, will force the Court to step in and protect German interests where necessary: 'in Germany, participation must, on the national level, comply with the requirements under Article 23.1 of the Basic Law (responsibility for integration) and can, if necessary, be asserted in proceedings before the [German] Federal Constitutional Court. ${ }^{38}$

Third, the Court extends the parliamentary control also to the areas of criminal law and social security law (Articles 48.2 and 82.2/82.3 TFEU). In these matter only, the Treaty stipulates (in Article 82.2/82.3 TFEU) that any member of the Council can raise an objection and prevent legislation by referring the matter to the heads of state and government in the European Council. This provision gives an indirect veto power to any government representative by preventing a decision from being taken. The Bundesverfassungsgericht, obsessed with the dominant position of the Member States as 'masters of the treaties' ${ }^{39}$, would be expected to support this additional safeguard for member states governments. Yet, it declares that the German Council member 'may only exercise this right on the instruction of the German Bundestag and, to the extent that this is required by the provisions on legislation, the Bundesrat. ${ }^{, 40}$ The judgement thus declares that the relevant accompanying law must be amended to take into account the involvement of the German Parliament. Effectively, what the Court has done is, however, weaken the national government. If the Court's demands were fulfilled German government representatives would be severely restricted in their actions and could not call for an ad hoc referral to the European Council because prior instructions to do so by the Bundestag are necessary. If anything, the Court paved the way for more not less

\footnotetext{
${ }^{38}$ BVerfG, 2 BvE 2/08 vom 30.6.2009, Absatz-Nr. 236.

${ }^{39} \mathrm{BVerfG}, 2$ BvE 2/08 vom 30.6.2009, Absatz-Nr. 231, 235, 271, 298, 334.

${ }^{40}$ BVerfG, 2 BvE 2/08 vom 30.6.2009, Absatz-Nr. 400.
} 
integration, because 'the more Community-friendly procedure is [and remains] the default. ${ }^{41}$

Since the obligation of the judgement, the German Bundestag has reconvened for a special session to amend the accompanying laws in order to guarantee compatibility with the Lisbon judgement. The Bundestag has ratified three new laws regulating the cooperation of government and parliament as well as three new laws regulating the cooperation between Bundestag and Bundesrat concerning matters related to the European Union ${ }^{42}$. The laws are in line with the judgement of the Court and thus require explicit instruction by the legislature for the government to act in areas of the passerelle and flexibility clauses. With regards to the aforementioned emergency clause, the Bundestag clearly saw the problems (i.e. its potential disability to act unless specifically instructed) and thus deviated from the judgement, stating instead that the government representative in the Council has to refer the issue to the European Council if instructed to do so by the German Parliament. The law does not, however, make the instruction a condition for referral meaning that the German government maintains the authority to act without the explicit instruction of the Bundestag or (where applicable) the Bundesrat ${ }^{43}$.

\section{Conclusion: The integration sunset?}

\footnotetext{
${ }^{41}$ Halberstam and Möllers (2009).

${ }^{42}$ See http://www.zeit.de/newsticker/2009/9/8/iptc-bdt-20090908-570-22334624xml; for the legislative documents (only available in German) see http://www.bundestag.de/dokumente/textarchiv/2009/26961025 kw37 begleitgesetz/index.html.

${ }^{43}$ The German states: '(1) Der deutsche Vertreter im Rat muss in den Fällen des Artikels 48 Absatz 2 Satz 1, des Artikels 82 Absatz 3 Unter- absatz 1 Satz 1 und des Artikels 83 Absatz 3 Unterabsatz 1 Satz 1 des Vertrags über die Arbeitsweise der Europäischen Union beantragen, den Europäischen Rat zu befassen, wenn der Bundestag ihn hierzu durch einen Beschluss angewiesen hat. (2) Wenn im Schwerpunkt Gebiete im Sinne des $\S 5$ Absatz 2 betroffen sind, muss der deutsche Vertreter im Rat einen Antrag nach Absatz 1 auch dann stellen, wenn ein ent- sprechender Beschluss des Bundesrates vorliegt.' See original Paragraph 9 of the Gesetze über die Ausweitung und Stärkung der Rechte des Bundestages und des Bundesrates in Angelegenheiten der Europäischen Union; Bundesdrucksache 16/13923. Available at http://dipbt.bundestag.de/dip21/btd/16/139/1613923.pdf.
} 
Overall, the judgement, although not preventing the Lisbon Treaty from entering into force, must be treated with great caution. Its potential for preventing future integration should not be under-estimated. If the German Constitutional Court is really going to find the (judicial) time and interest to apply its self-conferred ultra vires review powers, we could soon see a clash between the European Court of Justice and the German Constitutional Court. It is now easy to envisage a situation whereby the European Court upholds a specific legislative measure because it considers it to fall within the legal competences of the European Union, whereas the German Constitutional Court takes a different view and claims legal superiority over the ECJ, thereby questioning (if not challenging) the fragile legal structure that holds together the EU legal order and sees EU legislation taken precedence over national legislation in case of conflict. The German Constitutional Court suggests in its Lisbon judgement that it will strike down EU legislation, even if the EU has competences to act, in case the legislation is not in line with the German constitution. If anything, the Lisbon Treaty narrows the scope of legislation that can be considered in line (see the abovementioned list of state-defining powers). Adding to this the well-established role model functioning of the German Court with regards to other European constitutional courts, the consequences could be much more devastating than even the Court might anticipate. ${ }^{44}$

This is not to say that the Lisbon Judgement marks the beginning of the end for the European integration process. Still, the Grundgesetz might say ' $\mathrm{Ja}$ ' to Lisbon, but the German Constitutional Court might not necessarily do the same when it comes to future integrationist moves at the European level. The highest court of the most populous member state has just replenished its judicial stockpile in anticipation of future EU

\footnotetext{
${ }^{44}$ In fact, the judgement has already motivated some conservative Czech Senators to demand increased control for the Czech parliament vis-à-vis its government with regards to passerelle and flexibility clause (L. Kubosova, 2009).
} 
ambitions to press forward with an ever closer and ever more integrated Union seemingly keen to become much more active in its defence of what it perceives to be its own German as opposed to European area of judicial competence. Thus, the Humboldt University might have to wait quite some time before another German foreign minister inspires its students with a European vision that is as bold as Joschka Fischer's and yet remains compatible with the latest views of Germany's Constitutional Court.

\section{Bibliography}

Blair, T. (2000). Prime Minister's Speech to the Polish Stock Exchange. Warsaw

Baquero Cruz, J (2008). 'The Legacy of the Maastricht-Urteil and the Pluralist Movement', European Law Journal, no.14

Chirac, J. (2000). Notre Europe. Berlin: Deutscher Bundestag

Donnelly, B. and L. Hoffmann (2003). The Role of National Parliaments in the European Union, Federal Trust Policy Brief, no. 3

European Union (2001). Declaration on the Future of the Union Declaration 23, Treaty of Nice, OJ C 80/85

Fischer, J (2001). From Confederation to Federation - Thoughts on the finality of European Integration. Berlin: Humboldt University.

Halberstam, D. and C. Möllers (2009). 'The German Constitutional Court says Ja zu Deutschland!', German Law Journal, no. 10

Hayward, J (2004). 'Parliament and the French government's domination of the legislative process', Journal of Legislative Studies, no. 10.

Jospin, L. (2000). Intervention sur 'L'avenir de l'Europe élargie', Paris.

Kiiver, P (2006). European Scrutiny in a Comparative Perspective, in P. Kiiver, The National Parliaments in the European Union - a Critical View on EU Constitution-Building, The Hague/London/New York: Kluwer Law International. 
Kubosovia, L (2009). 'Czech senators in fresh move against Lisbon treaty', in EU Observer, 20 August 2009, available at http://euobserver.com/9/28566.

Larking, S. (2008). 'Debunking the Idea of Parliamentary Sovereignty: The Controlling Factor of Legality in the British Constitution', Oxford Journal of Legal Studies, no. 28.

Official Journal of the European Union (2004), Treaty Establishing a Constitution for Europe, Brussel.

Rau, J. (2001), Unity in diversity: What political form for Europe?, Berlin.

Schorkopf, F. (2009). 'The European Union as An Association of Sovereign States: Karlsruhe's Ruling on the Lisbon Treaty', German Law Journal, no. 10.

Weiler, J. (1995), 'The state 'über alles' - Demos, Telos and the German Maastricht Decision', EUI Working Papers, no. 19. 